\title{
ダム貯水池における 水温予測精度向上のための放射推定 IMPROVEMENTS OF RADIATION ESTIMATIONS FOR A SIMULATION OF WATER TEMPERATURE IN A RESERVOIR
}

\author{
矢島 啓 1 ・山本 茂友 2 \\ Hiroshi YAJIMA and Shigetomo YAMAMOTO \\ 1正会員 博(工) 鳥取大学大学院准教授 社会基盤工学専攻（二 $680-8552$ 鳥取市湖山町南4-101） \\ 西オーストラリア大学 Centre for Water Research 特任上級研究員 \\ 2学生会員 鳥取大学大学院 社会基盤工学専攻（干680-8552 鳥取市湖山町南4-101）
}

\begin{abstract}
The heat budget at water surface is composed of short- and long-wave radiations and latent- and sensible-heats. In this paper we improved the estimation of short- and long-wave radiations that have major effects on the water temperature change in a reservoir by analyzing observed radiation data at Tono Reservoir and simulating water temperature in the reservoir. The results are summarized as follows: 1) we can improve short-wave albedo by an equation that takes solar zenith angle, wind speed, humidity and scattered light ratio as parameters, 2) downward long-wave radiation estimation can be improved by considering not only cloudiness but also air temperature and proper emissivity, 3) the observed emissivity for upward long-wave radiation was 0.99 and 4) the accuracy of the downward long-wave radiation has more effect for improving water temperature estimation in a reservoir than short-wave albedo.
\end{abstract}

Key Words: short- and long-wave radiations, albedo, water surface, reservoir, water temperature

\section{1. はじめに}

水面における熱収支は，短波放射，長波放射，潜熱， 顕熱によって構成されており，この中で大きなエネル ギーを占めるのは，短波放射，および長波放射である. 地球大気の上端で，太陽光に垂直な面に入射する太陽の エネルギーは平均して $1.37 \times 10^{3} \mathrm{~W} / \mathrm{m}^{2}$ (太陽定数) である. そして, 地球大気や雲, エーロゾルなどによる散乱・反 射・吸収の結果, 中緯度帯では最大 $1,000 \mathrm{~W} / \mathrm{m}^{2}$ 以上の工 ネルギーが地球表面に達する. 地球表面の約7割である 海面を含む水面に注目すると，水面に達した短波放射は 一部が反射し，残りが透過および水に吸収される．この 水面に入射する放射と, 水面から反射される放射の比は アルベドと呼ばれる.

海面におけるアルベドは，大気と海洋の熱収支を大き く変え大気循環に大きな影響を与えることから様々な研 究者による実証研究がなされている. PayneやTaylorら は，太陽の天頂角を用いてアルベドをモデル化し1),2), Hansenらは，風の影響で水面が波立ち短波放射の入射角 が変わることでアルベドが小さくなることを考慮したモ デルを提案した ${ }^{3)}$. さらにJinらは，天頂角や風速だけで なく，大気のエアロゾルや雲が短波放射を散乱させるこ とでアルベドに影響を与え，415nmの波長では表層の植 物プランクトンによって短波放射が吸収されアルベドが 減少することを示した4). しかしながら，これらの多く の研究は海面を対象としており，一般に規模の小さな水 面である貯水池や湖沼における水温予測計算では，季節 的な太陽高度の違いのみを考慮してアルベドを評価する ことが多い5).

一方，水面に達する大気からの長波放射は，気温と水 蒸気圧によって増減する. 具体的には気温と水蒸気圧が 高い場合は増加し, 低い場合は減少することが知られて いるの. このことから，気温と水蒸気圧を変数とする複 数の下向き長波放射のモデルが提案されている. Silva は，快晴日のデータを用いて下向き長波放射のモデル化 を行った ${ }^{7)}$.また, Duarteらは, 快晴日と曇天日のデー 夕を解析し下向き長波放射のモデル化を行った ${ }^{8)}$. しか しながら，下向き長波放射の推定式は経験式であるため， あらゆる環境で適用可能であるとはいえない.また，ダ 么貯水池や湖沼での詳細な長波放射の研究はなされてお らず，さらに，長波放射の観測自体行われていない場合 が多い，そのためダム貯水池の長波放射推定には，国外 の研究データから構築された式を用いることが多い9.

以上のことから，ダム貯水池や湖沼において精度の高 い水温の予測計算を行うにはアルベドの変動を考慮し, 
観測地点に合った長波放射の推定式を構築する必要があ る.また，ダム貯水池においては，精度の高い水温を予 測することで，放流水の水温制御の効果的な運用に繋が ると考えられる。 そこで，本研究では主な気象要素を水 面上で計測している殿ダム貯水池(鳥取市東部に位置)を 対象に，実測データを用いて短波アルベドと長波放射の 推定式を構築し, その推定精度を評価する. また, 推定 式の一般性を確かめるために, 対象年度を変えて構築し た推定式を適応する.さらに，それぞれの構築された推 定式を用いて，ダム貯水池における水温予測精度を3次 元水理計算モデル（ELCOM）でシミュレーションを行 い，放射推定精度が水温予測に与える影響を評価する.

\section{2. 対象ダム貯水池と使用データおよび検討方法}

\section{(1) 研究の対象ダム貯水池}

殿ダム（北緯35度26分57秒，東経134度20分32秒）は， 国土交通省が鳥取市内に建設し, 平成23年度から運用を 行っている多目的のロックフィルダムである. 湛水面積 $0.64 \mathrm{~km}^{2}$, 総貯水容量 1240 万 $\mathrm{m}^{3}$, 有効貯水容量 1120 万 $\mathrm{m}^{3}$, 平常時最高水位(EL 182.8m)における最大水深は約 $37.8 \mathrm{~m}$ である ${ }^{10)}$ (図-1参照)。

\section{（2）使用データ}

\section{a) 気象データ}

殿ダム完成時から網場付近に設けられたフロート上 （図-2）で，風向風速，気温，湿度，気圧，4成分の放射 量（短波と長波のそれぞれ上向きと下向き）を10分間 隔で観測している。本研究において，予備検討からア ルベドにあまり寄与しないことが示唆された風向を除 いた，風速，気温，湿度，気圧，4成分の放射量の観測 值を解析に使用する.さらに，短波放射が散乱するこ とで，短波アルベドに影響があるため ${ }^{4)}$, 全天日射量に 対する散乱光の割合も使用する. ただし，この観測值 はないため，まず，緯度，月日，気圧などから全天日 射量求め, それをもとに湿度や太陽の天頂角から散乱 光成分を求める ${ }^{9)}$.

また，殿ダムで観測されていない雲量，視程は鳥取 地方気象台で3時間ごと（ただし0時は観測されていな い)に観測されたデータを使用した。また，雲量 $0+$ は 0.5 ，雲量10-は9.5として扱った.

\section{b) 水質データ}

気象観測位置から約 $200 \mathrm{~m}$ 下流の選択取水塔側面にお いて, 水面からEL.160mの範囲において, 水温, 濁度, 電気伝導度, Chl.a, 溶存酸素, pHの6水質項目を最小 1 時間間隔で観測している. 水質データからは水面の水 温と短波アルベドに影響を及ぼすと考えられる濁度, Chl.aを解析に使用する.ただし, 気象と水質の観測位 置の違いによる差異は小さいと考えられるため, ここ
では位置の違いによる影響を考慮しない.

\section{（3）放射推定式の検討方法}

\section{a）短波アルベドの推定方法}

推定式の構築は，重回帰分析を用いて行う。ただし， 多重共線性の問題から，得られたデータ全てを短波アル ベドの説明変数とすることはできない可能性がある.こ の多重共線性に関する指標として，VIF(Variance Inflation Factor)がある.VIFが大きいほど多重共線性の 影響があり，一般にVIFが5より大きいと多重共線性の 可能性があるとされている11)。そこで本研究では，まず, 全ての変数のVIFが5以下になるよう多変量解析ソフト SPSS Statistics ver.21を用いて変数の選定を行う.

次に、選定された変数を用いて, 式(1a), 式(1b), 式 (1c)に示す3の形式による推定式を用いて，短波アルベ ドの推定式を構築する.

$$
\begin{aligned}
& \alpha_{1}=a_{1} x_{1}+a_{2} x_{2}+\cdots+a_{i} x_{i} \\
& \alpha_{2}=\exp \left(a_{1} x_{1}+a_{2} x_{2}+\cdots+a_{i} x_{i}\right) \\
& \alpha_{3}=a_{1} x_{1}(1-y)^{b_{1}}+a_{2} x_{2}(1-y)^{b_{2}}+\cdots+a_{i} x_{i}(1-y)^{b_{i}}
\end{aligned}
$$

ここで， $\alpha_{1}, \alpha_{2}, \alpha_{3}$ はアルベド， $x_{1}, x_{2}, \cdots, x_{i}$ は天頂角 の余弦以外の短波アルベドの説明変数, $y$ は天頂角の余 弦， $a_{1}, a_{2}, \cdots, a_{i}$ と $b_{1}, b_{2}, \cdots, b_{i}$ は係数である.

式(1a)は線形型，式(1b)は指数型，式(1c)は全ての項に 天頂角の余弦の変数を含むモデルである，これは，天頂 角の大きさによって各変数の短波アルベドに与える影響

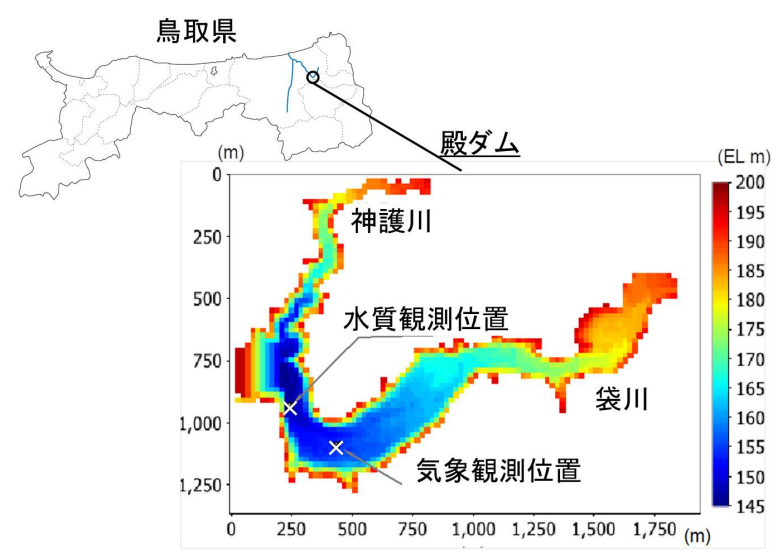

図-1 殿ダム貯水池の位置

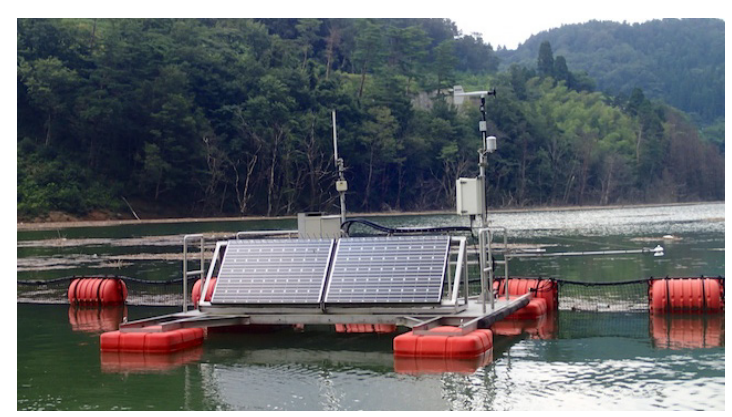

図-2 殿ダム貯水池の気象観測装置 
が異なることを反映するためである.

\section{b）下向き長波放射の推定方法}

大気中には温室効果気体があり, 水蒸気や二酸化炭素 などが長波放射を放出する，また，温室効果気体の中で も長波放射に最も寄与するのは水蒸気である. さらに, 水蒸気に比べ, 雲は放射量が大きいため雲の効果も考慮 した式(2a)，式(2b)が一般的に下向き長波放射の推定式 として使用されている8

$$
\begin{aligned}
& L_{D 1}=L\left(1+a C^{b}\right) \\
& L_{D 2}=L\left(1-C^{r}\right)+\delta C^{r} \sigma T_{a}^{4} \\
& L=\varepsilon \sigma T_{a}^{4}
\end{aligned}
$$

ここで， $L_{D 1}, L_{D 2}$ は下向き長波放射 $\left(\mathrm{W} / \mathrm{m}^{2}\right), \varepsilon$ \&気の射 出率， $T_{a}$ は気温(K), Cは雲量(0-1), $\sigma$ はステファン・ボ ルツマン定数 $=5.67 \times 10^{-8}\left(\mathrm{~W} / \mathrm{m}^{2} \mathrm{~K}^{4}\right), a, b, r, \delta$, は係数 である.

さらに, 式(2c)の変数であるとは, 水蒸気量が多いと黒 体放射 $(\varepsilon=1)$ に近づき, 水蒸気量が少ないと小さくなる. そのため，\&は様々な推定式が提案されている，そこで，

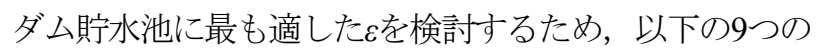
推定式について評価を行う.

$$
\begin{array}{ll}
\varepsilon_{1}=0.605+0.048 \sqrt{e_{a}} & (3 \mathrm{a})^{12)} \\
\varepsilon_{2}=1-0.261 \exp \left(-0.000777\left(273-T_{a}\right)^{2}\right) & (3 \mathrm{~b})^{13)} \\
\varepsilon_{3}=1.24\left(e_{a} / T_{a}\right) & (3 \mathrm{c})^{14)} \\
\varepsilon_{4}=0.83-0.18 \times 10^{-0.067 e_{a} / 10} & (3 \mathrm{~d})^{15)} \\
\varepsilon_{5}=0.52+0.205 \sqrt{e_{a} / 10} & (3 \mathrm{e})^{12)} \\
\varepsilon_{6}=1.723\left(e_{a} / 10 T_{a}\right)^{1 / 7} & (3 \mathrm{f})^{14)} \\
\varepsilon_{7}=0.79-0.17 \exp \left(-0.96 e_{a} / 10\right) & (3 \mathrm{~g})^{16)} \\
\varepsilon_{8}=0.7+0.0000595 e_{a} \exp \left(1500 / T_{a}\right) & (3 \mathrm{~h})^{17)} \\
\varepsilon_{9}=0.92-0.7 \times 10^{-1.2 e_{a} / 10} & (3 \mathrm{i})^{18)}
\end{array}
$$

ここで， $e_{a}$ は水蒸気土 $(\mathrm{hPa}), T_{a}$ は気温 $(\mathrm{K})$ を示寸.

推定式の構築は式(2a) と式(2b)の下向き長波放射の推 定式2ケースと式(3a)〜式(3i)の射出率の推定式9ケースを 組み合わせ, 合計18ケースの重回帰分析を行い, 係数 $a$, $b, r, \delta$ を決定し式の構築を行う.

\section{c）上向き長波放射の推定方法}

上向き長波放射の推定式を式(4)に示寸.

$$
L_{U}=\varepsilon_{w} \sigma T_{w}^{4}
$$

ここで， $L_{U}$ は上向き長波放射 $\left(\mathrm{W} / \mathrm{m}^{2}\right) ， \varepsilon_{w}$ は水面の射出率， $T_{w}$ は水面の水温 $(\mathrm{K})$ である. 上向き長波放射の推定方法 は, 殿ダム貯水池で観測された水面の水温と上向き長波 放射から， $\varepsilon_{w}$ の平均值を求める.

\section{d）精度の検討方法}

上に示したa） c)の各推定式の精度の検討は，各推定 値と観測值の比較から， RMSE(残差標準偏差), $\mathrm{AE}$ (絶 対誤差), $\mathrm{R}^{2}$ (決定係数)を求めて行う. また, 各推定式の
構築は2012年度 (2012年4月1日〜2013年3月31日)を対象 とする. また，構築された推定式の一般性の確認は， 2013年度 (2013年4月1日〜2014年3月31日)を対象とする. さらに，放射推定精度が水温に与える影響を評価するた め, 構築された各推定式のうち, 最も精度が高い推定式 について，短波アルベドと下向き長波放射，それぞれ 1 つずつ選択し水温のシミュレーションを行う.ただし， 上向きの長波放射については $\varepsilon_{w}$ を, 観測值から得られた 平均値に変更し評価することとする.

\section{（4）3次元水理計算モデルELCOMIこよる水温計算の方法}

水温の再現計算には西オーストラリア大学Centre for Water Researchで開発されたELCOMを用いる.

\section{a) ELCOMの概要)}

ELCOMは様々な環境外力に応じて変動する成層化され た水塊の時間的挙動を解析するために適用される流体力学 およひ熱力学の数值計算モデルである. 流れ場の数值計算 には，静水圧近似を仮定した非圧縮性流体に対寸る非定常 ナビエ・ストークス方程式を解いている. モデリング過程 には大気圧，コリオリカ, 潮汐, 風によるせん断力, 水表 面における熱収支, 塩分や熱量, その他スカラー量の輸送, 流入および流出を含んでいる. 以下にELCOMで用いられ ている短波放射および長波放射に関する式を示寸. ・短波アルベド

$$
\alpha=0.08+0.02 \sin \left(\frac{2 \pi j}{D}+\frac{\pi}{2}\right)
$$

ここでDは365, $j$ は1年j番目の日を表す.

・短波放射の水深方向一の熱輸送

$$
S_{D}(z)=S_{n e t} \exp (-\eta z)
$$

ここで， $S_{D}$ は短波放射 $\left(\mathrm{W} / \mathrm{m}^{2}\right) ， S_{n e t}$ は正味の短波放射 $\left(\mathrm{W} / \mathrm{m}^{2}\right), z$ は水深 $(\mathrm{m}), \eta$ は熱輸送量に対する消散係数 $\left(\mathrm{m}^{-1}\right)$ である.

ELCOMでは波長ごとに熱輸送量に対する消散係数を 設定することができ, 波長にはPAR(0.4 0.7 $\mu \mathrm{m})$, $\operatorname{NIR}(0.7 \sim 2.5 \mu \mathrm{m}), \quad \mathrm{UVA}(0.32 \sim 0.4 \mu \mathrm{m}), \quad \mathrm{UVB}(0.28 \sim 0.32 \mu \mathrm{m})$ の4種類がある．デフォルトでは，PARの消散係数は $0.25 \mathrm{~m}^{-1}, \mathrm{NIR}$ の消散係数を $1.0 \mathrm{~m}^{-1}$, UVAの消散係数を $1.0 \mathrm{~m}^{-1}, \mathrm{UVB}$ の消散係数を $2.5 \mathrm{~m}^{-1}$ である.

・長波放射

$$
\begin{aligned}
& L_{D E}=L\left(1+0.17 C^{2}\right) \\
& \varepsilon_{E}=9.37 \times 10^{-6} T_{a}^{2} \\
& L_{U E}=\varepsilon_{w} \sigma T_{w}^{4}
\end{aligned}
$$

ここで， $L_{D E}$ は下向き長波放射 $\left(\mathrm{W} / \mathrm{m}^{2}\right) ， \varepsilon_{E}$ は大気の射出率， $L_{U E}$ は上向き長波放射 $\left(\mathrm{W} / \mathrm{m}^{2}\right) ， \varepsilon_{w}$ は水面の射出率であり 0.96である. 


\section{b) 計算条件の設定}

計算のための貯水池形状のモデルグリッドは，全領域 一様の水平方向に $20 \mathrm{~m}$ ，鉛直方向に $0.5 \mathrm{~m}$ とする. また， 水温計算において重要なパラメータである光の消散係数 は，殿ダム貯水池における現地観測の結果よりPARの消 散係数を $0.7 \mathrm{~m}^{-1}$ に設定し，NIR，UVA，UVBはデフォル トのまま使用した。

水温の再現計算については，放射推定精度による水温 予測精度の評価を行うため, ELCOMに入力寸る放射推 定值を変更してシミュレーションを行った．また，計算 期間については, 成層が生じて発達する2012年5月15日 0:00から2012年8月1日0:00までを対象とした。

\section{3．短波アルベドと長波放射の推定結果}

\section{（1）短波アルベドの推定式の精度結果}

多変量解析ソフトSPSS Statistics ver.21を用いて選定さ れた変数は天頂角の余弦, 湿度, 風速, 散乱光の割合で あった. これらを用いて作成した重回帰式の精度の検討 のため, 推定した短波アルベドから求めた短波の正味放 射量と観測值を比較した結果を表-1に示す. 最も高い精 度が得られたのは，式(1c)による回帰式(図-6中の $\alpha_{3}$ の推 定式参照, $x_{1}$ : 湿度 $(\%), x_{2}$ : 風速 $(\mathrm{m} / \mathrm{s}), x_{3}$ : 散乱光の割合 (\%))であり, RMSEは $8.4 \mathrm{~W} / \mathrm{m}^{2}, \mathrm{AE} 4.9 \mathrm{~W} / \mathrm{m}^{2}, \mathrm{R}^{2}$ は 0.99であった. また, ELCOMで用いられている推定式 である式(6)による結果は，RMSEは17.4W/ $/ \mathrm{m}^{2} ， \mathrm{AE}$ $11.8 \mathrm{~W} / \mathrm{m}^{2}$ であり, 式(1c)よりも精度が劣っていた.

\section{（2）下向き長波放射の推定式の精度結果}

構築された下向き長波放射推定式より求めた推定值と 観測值を比較した. 下向き長波放射の推定式である式 (2a)，式(2b) と射出率の推定式である式(3a)〜式(3i)の各 組合せの推定精度の比較を表-2に示し, 精度の高い式の 組合せによる推定值と観測值の比較（日平均）を図-3に 示す．まず，表-2より式(2a)と各射出率の推定式の組合 せのうち, 高い精度を得たのは式(2a) と式(3d)を用いた 組合せであり, RMSEは27.4W $/ \mathrm{m}^{2}, \mathrm{AE} 23.0 \mathrm{~W} / \mathrm{m}^{2}, \mathrm{R}^{2}$ は0.76であった（図-3中の $L_{D 1}, \varepsilon_{4}$ 参照）。同様に, 式 表-1＼cjkstart観測値と比較した短波放射の正味放射量推定値の精度結 果(赤字は最も精度が高い值)

\begin{tabular}{c|ccc}
\hline 短波アルベド推定式 & $\mathrm{RMSE}\left(\mathrm{W} / \mathrm{m}^{2}\right)$ & $\mathrm{AE}\left(\mathrm{W} / \mathrm{m}^{2}\right)$ & $\mathrm{R}^{2}$ \\
\hline \hline 式(1a) & 9.1 & 5.2 & 0.99 \\
式(1b) & 8.3 & 5.3 & 0.99 \\
式(1c) & 8.4 & 4.9 & 0.99 \\
式(6) & 17.4 & 11.8 & 0.99 \\
\hline
\end{tabular}

(2b)の場合は式(3c)を用いた推定值の精度が，最も高く RMSEは24.5W/ $\mathrm{m}^{2} ， \mathrm{AE} 19.4 \mathrm{~W} / \mathrm{m}^{2} ， \mathrm{R}^{2}$ は0.80であった (図-3中の $L_{D 2}, \varepsilon_{3}$ 参照)

また，ELCOMで採用されている長波放射の推定式で ある式(8a) と式(8b)から推定した值と観測值の比較から 得られた結果は，RMSEは $35.9 \mathrm{~W} / \mathrm{m}^{2}$ ，AEは $28.9 \mathrm{~W} / \mathrm{m}^{2}$, $\mathrm{R}^{2}$ は0.58であり，式(2b)と式(3c)を用いた場合の方が，精 度が高いことが確認された(表-2).

\section{（3）上向き長波放射の推定式の精度結果}

殿ダム貯水池における観測值から求めた水面の射出率 の平均值は0.99であった．そこで水面の射出率を 0.99 と したときの上向き長波放射の推定精度の評価を行った結 果, RMSEは $4.9 \mathrm{~W} / \mathrm{m}^{2}, \mathrm{AE} 3.8 \mathrm{~W} / \mathrm{m}^{2} ， \mathrm{R}^{2}$ は 0.98 であっ た. 比較のため, 現在ELCOMで用いられている水面の 射出率 0.96 として, 同様に精度評価をすると，RMSEは $12.4 \mathrm{~W} / \mathrm{m}^{2} ， \mathrm{AE} 4.9 \mathrm{~W} / \mathrm{m}^{2} ， \mathrm{R}^{2}$ は 0.98 であり，水面の射 出率を 0.96 とするのは, 実際の射出率に比べ低い值であ ることが明らかとなった。

\section{4. 構築した推定式の殿ダムでの一般性の確認}

殿ダム貯水池における2013年度のデータを用いて構築 した各推定式の一般性を確認した。

推定した短波アルベドから求めた短波の正味放射量と 観測された正味放射量を比較した結果を表-3に示す．表 -3から，2012年度と2013年度のAE，R ${ }^{2}$ の值に変化は無 <, RMSEは2012年度よりも2013年度の結果は $0.1 \mathrm{~W} / \mathrm{m}^{2}$ 小さいが，ほぼ同程度であった。

同様に下向き長波放射の推定式においても一般性の 確認を行った結果を表-3に示し，推定值と観測值の比較

表-2 観測値と比較した下向き長波短波放射推定値の精度結果 (赤字は最も精度が高い値).

\begin{tabular}{c|ccc|ccc}
\hline \multirow{2}{*}{$L_{D}$} & \multicolumn{3}{|c|}{ 式(2a) } & \multicolumn{3}{c}{ 式(2b) } \\
\cline { 2 - 7 } & $\mathrm{RMSE}\left(\mathrm{W} / \mathrm{m}^{2}\right)$ & $\mathrm{AE}\left(\mathrm{W} / \mathrm{m}^{2}\right)$ & $\mathrm{R}^{2}$ & $\mathrm{RMSE}\left(\mathrm{W} / \mathrm{m}^{2}\right)$ & $\mathrm{AE}\left(\mathrm{W} / \mathrm{m}^{2}\right)$ & $\mathrm{R}^{2}$ \\
\hline \hline 式(3a) & 30.5 & 24.3 & 0.70 & 24.5 & 19.4 & 0.80 \\
式(3b) & 30.9 & 24.8 & 0.69 & 25.2 & 20.1 & 0.79 \\
式(3c) & 33.0 & 25.9 & 0.65 & 24.5 & 19.4 & 0.80 \\
式(3d) & 27.4 & 23.0 & 0.76 & 27.3 & 22.5 & 0.76 \\
式(3e) & 36.1 & 29.2 & 0.57 & 25.0 & 20.0 & 0.80 \\
式(3f) & 33.5 & 26.2 & 0.64 & 24.5 & 19.4 & 0.80 \\
式(3g) & 28.9 & 23.9 & 0.73 & 26.1 & 21.3 & 0.78 \\
式(3h) & 31.0 & 25.9 & 0.69 & 25.5 & 21.3 & 0.79 \\
式(3i) & 36.0 & 29.1 & 0.58 & 28.8 & 24.1 & 0.73 \\
\hline
\end{tabular}




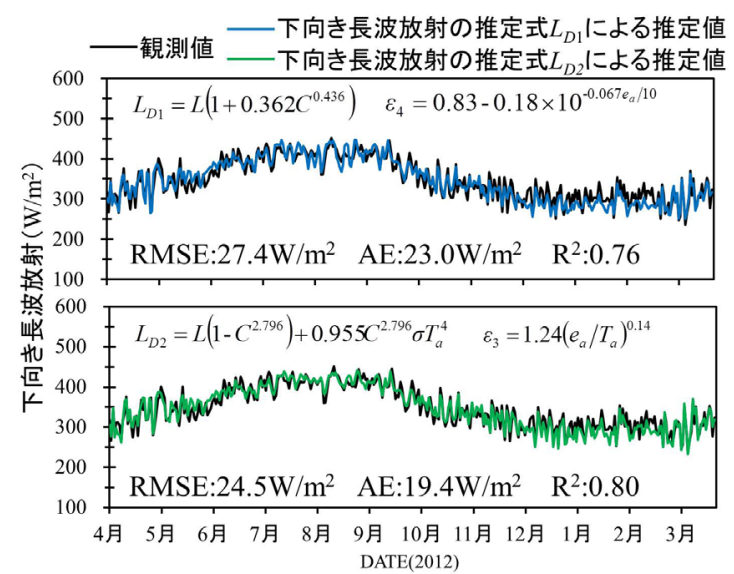

図-3 構築した下向き長波放射の推定式のうち精度が高い組 合せの式による推定值と観測値の比較(日平均).

表-3 推定式を構築した年と推定式の一般性を確認した年の 放射推定値の精度結果.

\begin{tabular}{|c|c|c|c|c|c|}
\hline & & 年度 & $\mathrm{RMSE}\left(\mathrm{W} / \mathrm{m}^{2}\right)$ & $\mathrm{AE}\left(\mathrm{W} / \mathrm{m}^{2}\right)$ & $\mathrm{R}^{2}$ \\
\hline \multirow{2}{*}{$\begin{array}{l}\text { 短 } \\
\text { 波 }\end{array}$} & \multirow{2}{*}{ 式(1c) } & 2012 & 8.4 & 4.9 & 0.99 \\
\hline & & 2013 & 8.3 & 4.9 & 0.99 \\
\hline \multirow{4}{*}{$\begin{array}{l}\text { 下 } \\
\text { 向 } \\
\text { き長 } \\
\text { 波 }\end{array}$} & 式(2a) & 2012 & 27.4 & 23.0 & 0.76 \\
\hline & 式(3d) & 2013 & 28.5 & 23.8 & 0.74 \\
\hline & 式(2b) & 2012 & 25.4 & 19.4 & 0.80 \\
\hline & 式(3c) & 2013 & 25.0 & 19.3 & 0.80 \\
\hline
\end{tabular}

（日平均）した図-4をみると，式(2a)と式(3d)を用いた 下向き長波放射の推定值の精度は2013年度ではRMSEは $1.1 \mathrm{~W} / \mathrm{m}^{2}, \mathrm{AE} 0.8 \mathrm{~W} / \mathrm{m}^{2}$ 増加し， $\mathrm{R}^{2}$ は0.02減少している が，大きな精度の変化はないといえる. また，式(2b)と 式(3c)を用いた推定值の精度の比較をみると，2013年度 ではRMSEは $0.4 \mathrm{~W} / \mathrm{m}^{2}, \mathrm{AE} 0.1 \mathrm{~W} / \mathrm{m}^{2}$ 減少しており, $\mathrm{R}^{2}$ に変化はない。

以上より，構築された推定式は，少なくとも殿ダム貯水 池においては高い精度を有していることが確認された。

\section{5. 放射推定精度改善による水温予測精度の向上}

\section{（1）放射推定精度と水温予測の結果}

水温の再現計算の結果を図-5に示す，まず，図-5から 上段の観測值と下段のELCOMで採用されている放射式 での再現結果を比較すると, 観測值に比べELCOMで採 用されている放射式を用いた場合，水温が低いことがわ かる (7月の標高 $180 \mathrm{~m}$ 付近の水温に着目).これは, ELCOMで採用されている下向き長波放射の推定值は, 観測值に比べ小さく推定されていることが原因である (年平均下向き長波放射で比較すると約 $15 \mathrm{~W} / \mathrm{m}^{2}$ 小さい). しかしながら，本研究で構築した放射式をELCOMモデ ルに適用した場合 (図-5中段) は観測值のコンター図と概 ね一致しており，再現性の向上を図ることができた.

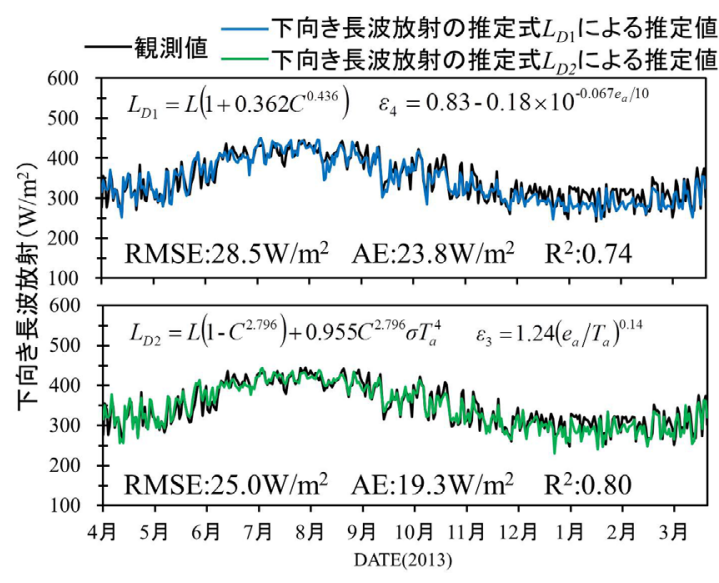

図-4 構築した下向き長波放射の推定式を2013年度の殿ダム に適用した場合の推定値と観測值の比較(日平均)。

（2）短波・長波放射が水面の水温予測精度に与える影響 水面の水温の再現計算について, 本研究で構築した推 定式による短波アルベドの推定值のみを適用した場合と 下向き長波放射の推定值のみを適用した場合で比較した 結果を図一に示す。

短波アルベドの推定值のみを適用した場合，再現性の 改善はあまりみられない，これは，短波放射は水表面を 透過する性質をもつため ${ }^{19}$ 水面の水温の再現計算におい ては影響が小さいためと推測される。一方，水面で吸収 される長波放射の推定值のみを適用した場合は大きく再 現性の向上がみられた．以上のことから水面の水温計算 において，短波のアルベドよりも，長波放射の精度が大 きな影響を与えることが明らかとなった。

\section{6. おわりに}

本研究では, 放射推定精度を改善することで，ダム貯 水池における水温の予測精度を向上させることを目的と して研究を行った. また, 3次元湖沼水理予測モデル ELCOMを用いて，放射推定の精度が水温予測に与える 影響を評価した。ここで得られた結果を以下にまとめる。 (1) 短波アルベドの推定には, 季節的な変化だけでなく, 太陽の天頂角, 風速, 湿度, 散乱光の割合を変数として 取り込むことで，その推定精度を高めることができた.

（2）下向き長波放射の推定には，気温のみならず，水蒸 気圧を変数として取り込まれている式(3c)を採用するこ とや, 式(2b)のような少し複雑な式を採用することで, 現在ELCOMで採用されている推定式よりも，観測值と の平均誤差を約 $10 \mathrm{~W} / \mathrm{m}^{2}$ 小さくすることができた.

(3) 上向き長波放射推定のパラメータである水面の射出 率を観測されたデータを基に検討し，射出率の年平均 值は0.99であった．これは，ELCOMで設定されている 射出率0.96よりも高い值であることが明らかとなった。

(4) 水温予測のシミュレーションでは, 本研究において 
${ }^{\circ} \mathrm{C}$

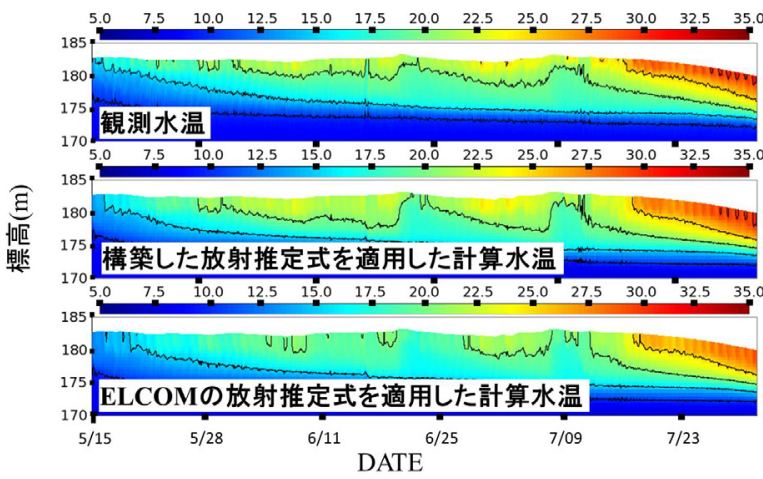

図-5 ELCOMモデルに適用する放射推定式を変更して行った 水温の予測シミュレーションの結果.

最も推定精度の高い放射推定式を用いることで，水温 の予測精度を向上させることができた．また，水温の 予測精度向上に大きく寄与したのは長波放射の推定精 度であり, 短波アルベドの推定精度は僅かであること を明らかとした。

以上, 本研究では2012年度の殿ダム貯水池を対象に放 射推定式の構築と水温の予測計算を行い, 水温の予測精 度を向上することができた．また，2013年度を対象とし ても, 構築した放射推定式の精度の確認も行うことがで きた. 今後は, 他のダム貯水池や湖沼において, 本研究 で構築された放射推定式の妥当性があるかの確認を行い, 水温予測における放射推定式の重要性を再確認していく 必要がある.

謝辞: 本研究で使用したデータは国土交通省中国地方整 備局鳥取河川国道事務所殿ダム管理支所より提供をいた だいた．また，本研究は，国土交通省河川砂防技術研究 開発（地域課題分野）の研究助成を受けて行われた。 こ こに記して謝意を表します。

\section{参考文献}

1) Payne, R. E.: Albedo of the sea surface, J. of the Atmospheric Sciences, 29, pp. 959-970, 1972.

2) Taylor, J. P. et al:: Studies with a flexible new radiation code. II: Comparisons with aircraft short - wave observations, Q. J. Roy. Meteor. Soc., 122, pp. 839-861, 1996.

3) Hansen, J. et al: Efficient three-dimensional global models for climate studies: Models I and II, Mon. Weather. Rev., 111, pp. 609-662, 1983.

4) Jin, Z. et al:: A parameterization of ocean surface albedo, Geophysical research letters, 31, pp.1-4, 2004.

5) ELCOM Science Manual: http://www.cwr.uwa.edu.au/software 1/CWRDownloads/modelDocs/ELCOM_Science.pdf, 2014.

6) Crawford, T. M. and Duchon, C. E.: An improved parameterrization for estimating effective atmospheric emissivity for use in calculating daytime downwelling longwave radiation, $J$. of

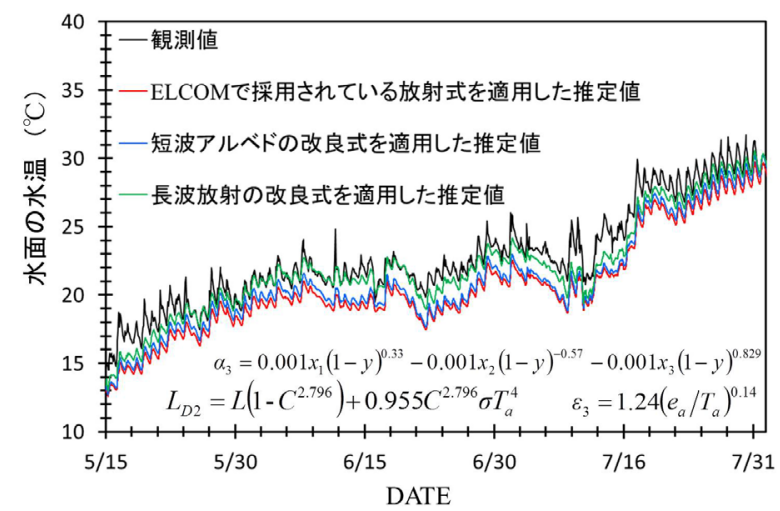

図-6 短波アルベドと長波放射の一方の推定式を改良した時 の水面の水温の再現計算結果と観測値の比較結果.

Applied Meteorology, 38, pp. 474-480, 1999.

7) Silva, R. C.: Estudo do balanço de radiação no pantanal sul matogrossense, Mestrado em meteorologia, Instituto Nacional de Pesquisas Espaciais, São José dos Campos, 2002.

8) Duarte, H. F. et al:: Assessing daytime downward longwave radiation estimates for clear and cloudy skies in Southern Brazil, Agr. Forest. Meteorol., 139, pp. 171-181, 2006.

9) 近藤純正：地表面に近い大気の科学, 東京大学出版会, pp.31-81, 2010.

10) 殿ダム管理支所 : 殿ダムの規模, http://www.cgr.mlit.go.jp/ tottori/tono/01dam/scale/index.html（引用2014-9-10)

11) Holder, A. J. et al: Chain melting temperature estimation for phosphatidyl cholines by quantum mechanically derived quantitative structure property relationships, J. of computer-aided molecular design 17, 2-4, pp. 223-230, 2003.

12) Brunt, D.: Notes on radiation in the atmosphere. I, Q. J. Roy. Meteor. Soc., 58, pp. 389-420, 1932.

13) Idso, S. B. and Jackson, R. D.: Thermal radiation from the atmosphere, J. Geophys. Res., 74, pp. 5397-5403, 1969.

14) Brutsaert, W.: On a derivable formula for long - wave radiation from clear skies, Water Resources Res., 11, pp. 742-744, 1975.

15) Ångström, A.: A study of the radiation of the atmosphere, Smithson. Misc. Collect, 65, pp. 1-159, 1916.

16) Garratt, J. R.: Extreme maximum land surface temperatures, J. of applied meteorology, 31, pp. 1096-1105, 1992.

17) Idso, S. B.: A set of equations for full spectrum and 8 - to $14-\mu \mathrm{m}$ and 10.5 - to 12.5 - $\mu \mathrm{m}$ thermal radiation from cloudless skies, Water resources Res., 17, pp. 295-304, 1981.

18) Keding, I.: Klimatologische Untersuchung ueber die atmosphaerische Gegenstrahlung und Vergleich vom Berechnungsverfahren anhand langjaehriger Messungen im Oberrheintal, Ber Dtsch. Wetterd, 178, 72pp., 1989.

19) 近藤純正：水環境の気象学, 朝倉書店, 350pp., 2011. 